\title{
RTI metoda jako způsob digitalizace kulturního dědictví
}

\author{
Barbora Borůvková, Klára Burianová
}

1 CHARR, Manuel. São Paulo Museum of Modern Art Opens on Minecraft. Museum Next [online]. Whitley Bay: Museum Next, 2021, 22. 6. 2021 [cit. 2021-9-16]. Dostupné z: https:/l www.museumnext.com/article/ sao-paulo-museum-of-modern-art-opens-on-minecraft/.

2 Web organizace: ne-mo.org. 3 Survey on the impact of the COVID-19 situation on museums in Europe: Final report [online]. Berlín: Network of European Museum Organisations, 2020 [cit. 20219-19]. Dostupné z: https:// www.ne-mo.org/fileadmin/ Dateien/public/NEMO documents/NEMO_COVID19. Report_12.05.2020.pdf.

Mgr. Barbora Borůvková barbora.boruvkova.2@uhk.cz Katedra pomocných věd historických a archivnictví Filozofická fakulta Univerzity Hradec Králové

Mgr. Klára Burianová klara.burianova@uhk.cz Katedra pomocných věd historických a archivnictví Filozofická fakulta Univerzity Hradec Králové

\section{Reflectance Transformation Imaging as a way of digitizing of the cultural heritage}

Abstract: Current technological developments offer an inexhaustible number of procedures for digitization. However, technological equipment intended for teams in professional laboratories reaches price levels that cultural institutions often do not have enough finances. Procedures and methods using equipment, which institutions often already own or are not so expensive to acquire, come to the fore. One of them is the RTI (Reflectance Transformation Imaging) method, which creates a spatial relief composed of a sequence of images with visible lighting. The RTI method is very successful in depicting illegible or wiped details and is already widely used in archaeology.

Keywords: Reflectance Transformation Imaging, Digitalization, Seals, Modern technologies, Cultural Heritage

\section{Úvod}

Rok 2021 prokázal, jak byl odmítavý postoj některých institucí, zaměřujících se na uchování kulturního dědictví, k digitalizaci památek zpátečnický. Přitom nejen pandemie COVID-19 nám všem ukázala, kolik zmůže on-line prohlídka galerie či muzea. Lze konstatovat, že právě digitální výstavy měly pozitivní dopad pro obě strany - instituce i veřejnost.

Institucím, jako jsou muzea, galerie, archivy a knihovny, se vládní restrikce nevyhnuly, a proto musely zareagovat novými způsoby.

Kreativitě se během pandemie meze nekladly. Př́́kladem je Museu de Arte Moderna de São Paulo, které své výstavní prostory přeneslo do počítačové hry Minecraft, známé svou specifickou grafikou. Třebaže tento projekt pravděpodobně cílil spíše na mladší a náctileté návštěvníky, splnil ještě jeden účel. Přenesl konkrétní muzeum do dětských pokojů, pracoven nebo obývacích pokojů po celém světě. ${ }^{1}$

Organizace Network of European Museum Organisations (NEMO) ${ }^{2}$ provedla od března do konce dubna 2020 studii dopadu pandemie COVID-19 přibližně v 1000 světových institucí, z toho českých bylo celkem
23. Podle této studie se jednou ročně k (fyzické) návštěvě muzea odhodlá pouze $42 \%$ Evropanů, přičemž ale $82 \%$ lidí zapojených do této studie je denně on-line.

Jak se pandemie projevila v muzeích, jejich struktuře a aktivitách? Téměř $80 \%$ muzeí upravilo pracovní náplň svých zaměstnanců, aby vyhovělo aktuálním požadavkům, až $30 \%$ muzeí přesunulo část svých zaměstnanců do digitalizačních týmů a $16 \%$ muzeí zvýšilo rozpočet na on-line aktivity. Velká část institucí využívala takové on-line činnosti, které byly finančně méně náročné, jako propagace na sociálních sítí (např. hashtagy), nebo rozšírily již stávající on-line služby. Aktivity, které vyžadovaly více času, finančních zdrojů, dovedností nebo technologií (např. podcasty, živý přenos nebo nové on-line přístupy), byly využívány o poznání méně. At' už byly on-line aktivity institucí jakkoli náročné, nárůst návštěvnosti těchto aktivit byl zaznamenán mezi 25-200 \%. Mezi konkrétní př́klady on-line aktivit můžeme zařadit digitální výstavu Rembrandtových děl v Museo Nacional Thyssen-Bornemisza v Madridu, které zaznamenalo zvýšenou návštěvnost o $53 \%$ v porovnání se stejným časovým úsekem v roce 2019. ${ }^{3}$ 
Již řadu let tedy vznikají po celém světě různé projekty, které si kladou za cíl co nejvěrohodněji zachovat kulturní dědictví dalším generacím. Účastní se jich knihovny, muzea, univerzity a mnohé další instituce. Některé spolupracují na mezinárodní úrovní, jiné pracují lokálně v místě svého působiště.

Pro trojrozměrnou digitalizaci existuje v současné době celá řada technologií v různých pořizovacích hodnotách a náročnosti. Velmi oblíbenou metodou nejen ve světě je fotogrammetrie, která je velmi ekonomicky př́ivětivá, rychlá a přesná. $\mathrm{V}$ principu se jedná o metodu vypočítávající rozměr a tvar $\mathrm{z}$ umístění konkrétních bodů ve 3D prostoru využitím série alespoň 30 fotografií snímaného objektu $\mathrm{z}$ různých stran a úhlů. Speciální software identifikuje společné prvky na fotografiích a pomocí nich sestaví 3D model. Nespornou výhodou této metody je uživatelská nenáročnost a nízké pořizovací náklady. ${ }^{4}$

Jedním z významných projektů současnosti je Rekrei, který si klade za cíl rekonstruovat zničené muzeum v Mosulu, k jehož destrukci došlo $\mathrm{v}$ roce 2015. Na webových stránkách projektu lze zhlédnout také videa již zrekonstruovaných předmětů, staveb atd. Projekt ale dále pokračuje rekonstrukcí kulturního dědictví v zemětřesením zasaženého Nepálu či dalšími památkami po celém světě. ${ }^{5}$

$\mathrm{V}$ kontextu moderních digitalizačních technologií nelze přehlédnout bezkontaktní 3D skenery, které mohou fungovat na různých principech - LiDAR, strukturované světlo či laser. Významnou institucí digitalizující světové kulturní dědictví je společnost IMA Solution využívající převážně skenery společnosti Artec. Skenery typu Artec3D Eva či Spider zachycují přesné textury a rozměry. ${ }^{6}$

Skenování za pomoci laseru se $\mathrm{v}$ oborech zabývajících se kulturním dědictvím objevuje až od přelomu tisíciletí. Oproti situaci v zahraničí, kde je laserové skenování využíváno delší dobu, u nás se snaží více a více zakotvit. Národní památkový ústav, územní odborné pracoviště Ústí nad Labem, $\mathrm{k}$ tomu vydal $\mathrm{v}$ roce 2015 metodickou príručku s přesnými popisy postupů?

U malých předmětů je základní princip digitalizace u všech metod stejný (taktéž i u RTI metody). Znehybněný předmět je třeba ze všech stran nasnímat (fotograficky či skenerem funguiícími na výše uvedených principech) a poté přenést do počítače a nechat zpracovat speciálním softwarem určeným pro konkrétní technologii. Dále pak záleží především na sledovaném cíli, proto se také volí konkrétní metoda digitalizace. Pro srovnání fotogrammetrie a 3D skenování menších předmětů vyšla $v$ roce 2016 studie M. Jurdy a P. Urbanové, která prokázala na kosterních pozůstatcích z Dolních Věstonic, že fotogrammetrie, tedy zachycení objektů pouhou fotografií a dalším jejím zpracováním, se plně vyrovná laserovému skenování. ${ }^{8}$ Lze tedy konstatovat, že i právě proto, $\mathrm{s}$ přihlédnutím $\mathrm{k}$ cenové dostupnosti fotoaparátů vůči 3D skenerům, je tato metoda jednou z nejpoužívanějších v současnosti.

Osobní návštěva pamětových institucí je nenahraditelná a jen málokomu dokáže současná technologie, ačkoli velmi vyspělá, nahradit atmosféru výstavních síní. Bohužel v inventárích snad každé pamětové instituce se nachází památka, jež již není ve stavu vhodném k vystavení. A právě zde mohou být moderní technologie více než užitečné. Nejenže je možné památku převést do on-line prostoru s cílem ukázat ji návštěvníkům a zároveň ji stále chránit ve vyhovujících konzervátorských podmínkách, ale dnešní moderní technika umožňuje zobrazit i takové detaily, které byly lidskému oku skryty. Mohou napomoci modernímu bádání, aniž by se badatel či vědec musel nacházet v konkrétní pamětové instituci.

Jak již nastínila studie organizace NEMO, instituce většinou zvolí levnější alternativy technologií. Není v možnostech každé instituce disponovat technologiemi v hodnotě několik milionů korun, avšak dnešní doba nabízí i takové možnosti, které přinesou kvalitní výsledky a zároveň jsou finančně únosné. Mezi ně se řadí
4 ZUZA, Mikolas.

Fotogrammetrie - 3D skenování s použitím fotoaparátu či mobilu. Https:/ljosefprusa.cz [online]. 2018 [cit. 2021-10-28]. Dostupné z: https:/ljosefprusa. czlfotogrammetrie-3d-skenovani-s-pouzitim-fotoaparatu-ci-mobilul.

5 https://projectmosul.org/ 6 Ima Solutions: 3D scanning \& digital media [online]. Francie, 2021 [cit. 2021-10-29]. Dostupné z: https://ima-solutions. fr/technologies-and-know-howl short-range-3d-scanning/. 7 BREJCHA, Marcel, Vladimír BRŮNA, Zdeněk MAREK a Bára VËTROVSKÁ. Metodiky digitalizace, $3 D$

dokumentace a $3 D$ vizualizace jednotlivých typů památek [online]. Ústí nad Labem, 2015 [cit. 26.10.2021].

Dostupné z: https://www.npu. cz/publikace/metodika-digitalizace-3d-dokumentace-a-3d-vizualizacejednotlivych-typu-pamatek.pdf 8 JURDA, Mikuláš a Petra URBANOVÁ. Threedimensional documentation of Dolní Věstonice skeletal remains:

can photogrammetry substitute laser scanning?

Anthropologie, Vol. 54, No. 2 (2016), pp. 109-116. 
9 Cultural Heritage Imaging [online]. San Francisco:

Cultural Heritage Imaging,

(c) 2002-2021 [cit. 2021-9-26].

Dostupné z: http://culturalheritageimaging.org/About_Us/.

10 BENTKOWSKA-KAFEL,

Anna a Lindsay MACDONALD.

Digital techniques for do-

cumenting and preserving

cultural heritage: Collection

Development, Cultural

Heritage, And Digital

Humanities [online]. Croydon:

ARC Humanities Press,

Kalamazoo and Bradford,

2017 [cit. 2021-9-26]. ISBN

9781942401346. Dostupné

z: https://library.oapen.org/

viewer/web/viewer.html?file=/ bitstream/handle/

20.500.12657/4278

$5 / 9781942401353$.

pdf? sequence $=1$ \&isAllowed $=y$.

11 Veškeré technické vybavení bylo pořízeno díky projektu specifického výzkumu s názvem Digitalizace vybraných sfragistických památek RTI metodou, jehož hlavní řešitelkou byla Mgr. Barbora Borůvková. Specifický výzkum vznikl pod záśtitou Filozofické fakulty Univerzity Hradec Králové $v$ roce 2021. např́klad RTI metoda digitalizace, o které budou následující řádky.

Článek vznikl jako výstup z projektu specifického výzkumu s názvem Digitalizace vybraných sfragistických památek RTI metodou pod záštitou Filozofické fakulty Univerzity Hradec Králové.

\section{RTI metoda digitalizace}

Reflectance Transformation Imaging, zkráceně RTI je specifická fotografická metoda digitalizace objektů, jež umožňuje velmi atraktivně zobrazovat strukturu objektu. Tato technika digitalizace funguje na základě informací o zdroji světla odraženého od povrchu digitalizovaného objektu. Pracuje též s informacemi o prostoru, úhlu a postavení světel, barevným spektrem a časem. Základní technikou RTI je tzv. mapování polynomiální textury (zkráceně PTM), jež umožňuje vizualizaci reliéfních povrchů pod různými úhly zdroje světla. V procesu zachycování snímků jsou zaznamenávány informace o postavení fotoaparátu, světel a stínů, což umožňuje speciálnímu RTI softwaru vylepšit povrchové vlastnosti a barevné atributy objektu pro kvalitnější zobrazení. Informace o zdroji světla jsou matematicky syntetizovány a vedou $\mathrm{k}$ tvorbě modelu povrchu. Digitalizační pracovník, který se ve vybraných institucích zabývá digitalizací, poté může interaktivně manipulovat se svítivostí, rozsvítit tak obraz v RTI softwaru a zkoumat detailní strukturu digitalizovaného objektu na monitoru počítače. Metoda RTI dokáže odhalit povrchové detaily, jež jsou oku badatele skryty. Výsledkem je stále dvourozměrná (2D) fotografie, disponující ovšem trojrozměrnou (3D) informací o povrchu.

Ve skutečnosti se jedná spíše o „2,5D“ snímek, nikoli př́mo o 3D. Pokud výsledek digitalizace otevřeme $\mathrm{v}$ RTI prohlížecím softwaru, pixely modelu jsou schopny odrážet „virtuální“ světlo, které na digitalizát vrhá prohlížecí software z jakékoli úhlu pohledu, jejž zvolíme. Díky změnám světel a stínů je možné pozorovat $\mathrm{i}$ jemné detaily 3D struktury digitalizovaného objektu.
Reflectance Transformation Imaging je metoda vyvinutá $\mathrm{v}$ laboratořích společnosti Hewlett-Packard Tomem Malzbenderem a Danem Gelbem. Metoda RTI původně vychází z Polynomial Texture Mapping (zkráceně $\mathrm{PTM}$ ), publikované $\mathrm{v}$ roce 2001, a od té doby prošla četným vývojem. Společnost Cultural Heritage Imaging, známá též pod zkratkou $\mathrm{CHI}$, se zaměřuje na zobrazování kulturního dědictví, jež se mimo jiné zabývá pomocí humanitním pracovištím zachraňovat historické památky. ${ }^{9}$

Obě zmíněné metody, RTI i PTM, jsou velmi oblíbené u ochránců kulturního dědictví. Není to pouze $\mathrm{z}$ důvodu ekonomického, ale také protože disponují atraktivním a uživatelsky př́větivým způsobem zobrazování objektů. Zároveň umožňují simulovat 3D efekt, který je $\mathrm{v}$ dnešní době tolik populární. Interaktivní ovládání směru osvětlení ve vizualizačním softwaru zlepšuje vnímání struktury povrchu ve srovnání se statickými 2D fotografiemi, čímž se zvyšuje čitelnost reliéfu, opisu, nápisů a obrazu na objektu. ${ }^{10}$

\section{Technické vybavení a software}

Technické vybavení pro digitalizaci RTI metodou se může $\mathrm{v}$ různých zdrojích a na různých pracovištích lišit, nicméně nelze se obejít bez digitálního DSLR fotoaparátu nebo mirrorless fotoaparátu s kvalitním světelným objektivem, stativu, osvětlení a malého lesklého černého objektu (většinou koule). Některá profesionální pracoviště disponují tzv. hemisférou (kopulí), kde jsou světla již prímo uchycena v konstrukci kopule a zachycení objektu tak neruší jiné zdroje světla nebo stíny. Podstatné je, aby digitální fotoaparát byl stabilně kolmo k digitalizovanému objektu. Zároveň je důležité, aby digitalizaci nenarušovaly pohyby a otřesy. Pro zjištění skutečnosti, zda je fotoaparát kolmo či podložka vodorovná poslouží vodováha. Digitalizační pracovník by měl být schopný digitální fotoaparát manuálně ovládat a zaostřit přesně na digitalizovaný objekt. Jako konkrétní př́klad lze uvést digitální fotoaparát Canon 90D s objektivem 
Canon EF 24-70 mm f/4,0 L IS US, který se osvědčil v Centru digitálních historických věd pod Katedrou pomocných věd historických a archivnictví Filozofické fakulty Univerzity Hradec Králové. Pro zajištění kolmosti byla též využita malá vodováha připevněná do sáněk těla digitálního fotoaparátu.

Světelné zdroje je třeba rozmístit přesně do stejné vzdálenosti od digitalizovaného objektu, který je umístěn přesně pod objektivem. Lze využít též externí blesk či bodové osvětlení. Vzdálenost světla od digitalizovaného objektu je nutné dodržet stejnou po celou dobu snímání.

Digitální fotoaparát může být uchycen na tripodu nebo napríklad na speciálním reprodukčním stojanu. Důležité však je, aby bylo možné manipulovat $s$ nastavením vzdálenosti digitálního fotoaparátu od objektu a aby byla zajištěna stabilita zařízení $\mathrm{v}$ kolmé poloze fotoaparátu $\mathrm{k}$ objektu. Pro zachycení správné barevnosti objektu je vhodné neutrální pozadí, tedy aby podložka byla bílá, šedá či černá. Pomoci může také neutrální šedá karta (18\% šedá) anebo kontrolní stupnice odstínů, která $18 \%$ šedou též obsahuje. ${ }^{11}$

Konkrétní technické vybavení bylo vybráno po konzultaci s odborníkem na digitalizaci z Národního archivu.

Černý lesklý objekt, např́klad kouli, je třeba umístit na podložku tak, aby zasahovala do snímané oblasti, byla v blízkosti objektu, ale zároveň ji lze umístit např. do rohu záběru, kde ji lze oříznout beze ztráty dat. Je nutné uvážit, jak na objekt budou dopadat stíny a pomocí světelných zdrojů $\mathrm{v}$ různých úhlech se je pokusit eliminovat. Černý lesklý objekt je ve scéně umístěn proto, aby byl software schopen detekovat postavení světel.

Pro potřeby pamětových institucí se nabízí možnost využít open source software ${ }^{12}$ již zmíněné společnosti Cultural Heritage Imaging. Pro vytvoření modelu je to např́klad RTIBuilder a k prohlížení výsledků RTIViewer. Pro spuštění programů je také třeba mít nainstalován programovací jazyk Java.

Hlavní vizí společnosti CHI je demokratizovat technologie a umožnit lidem na celém

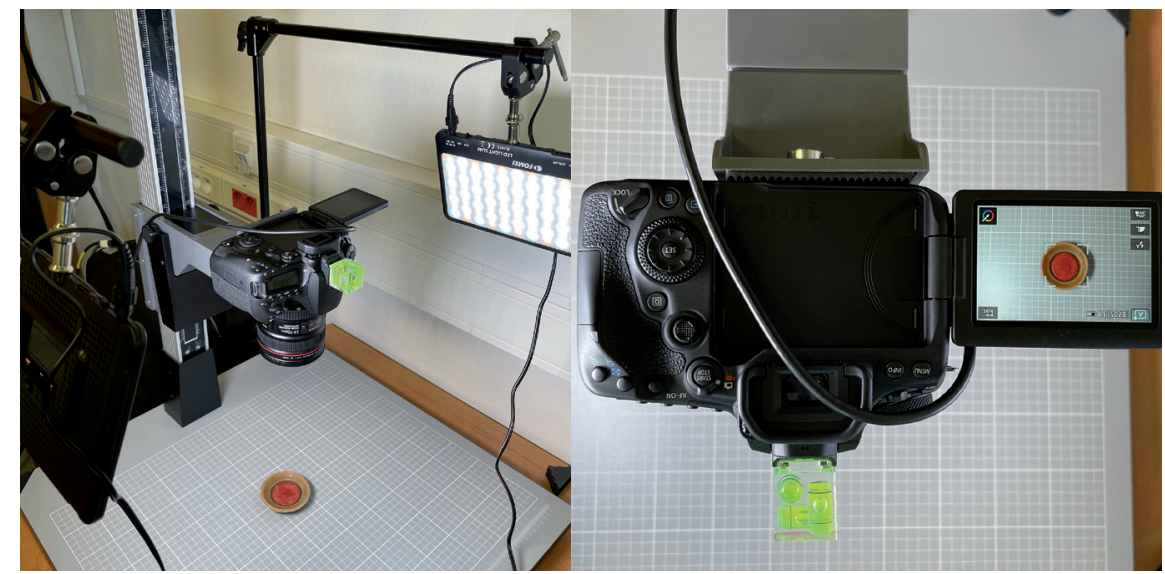

světě dokumentovat vlastní kulturní dědictví, pomáhat ho uchovávat a chránit pro budoucí generace. Společnost $\mathrm{CHI}$ spojuje profesionální pracoviště např́ič vědními obory - archeologická naleziště, muzea nebo obory prírodovědných věd. ${ }^{13}$

\section{RTI digitalizace pečetí na Univerzitě Hradec Králové}

V rámci nově vzniklé digitální laboratoře Centrum digitálních historických věd pod Katedrou pomocných věd historických a archivnictví Filozofické fakulty Univerzity Hradec Králové je jednou z aktuálních činností digitalizace sbírky pečetí Náchodského muzea. RTI metoda byla $\mathrm{v}$ př́padě digitalizace této sbírky zvolena z několika důvodů. Ačkoli digitální laboratoř disponuje několika profesionálními $3 \mathrm{D}$ zařizeními, tak pečeti různých velikostí i barev jsou i pro 3D profesionální skenery poměrně komplikované na zachycení. Mnohdy mají více či méně setřený otisk, jsou tmavé, a tudíž pro 3D skenery špatně viditelné, nebo jsou př́liš malé a výsledkem není dostatečně kvalitní digitalizát. Pro potřeby muzea je nutné pořídit skutečně kvalitní digitalizáty. $Z$ tohoto důvodu vznikl specifický výzkum s názvem Digitalizace vybraných sfragistických památek RTI metodou pod záštitou Filozofické fakulty Univerzity Hradec Králové a ve spolupráci s Náchodským muzeem právě probíhají digitalizační práce.

RTI snímky byly zachyceny digitálním fotoaparátem Canon 90D a objektivem Canon EF 24-70 mm f/4,0 L IS US s využitím reprodukčního stojanu a sady čtyř LED světel. Dvě LED světla jsou přichycena přímo na reprodukčním stojanu a dvě mimo na stativech ve stejné vzdálenosti od digitalizované pečeti. Snímání probíhá prostřednictvím software RTIBuilder
Obr. 1. Reprodukční stojan
12 Open source je tzv. otevřený software s legálně dostupným zdrojovým kódem. 13 Společnost CHI: http://culturalheritageimaging.org. 
14 Documenting and Interpreting Petroglyphs and Inscriptions at El Morro National Monument [onli-

ne]. San Francisco: Cultural Heritage Imaging, ( 2002-2021 [cit. 2021-9-26]. Dostupné z: http://culturalheritageimaging. org/What_We_Do/Projects/elmorrolindex.html.
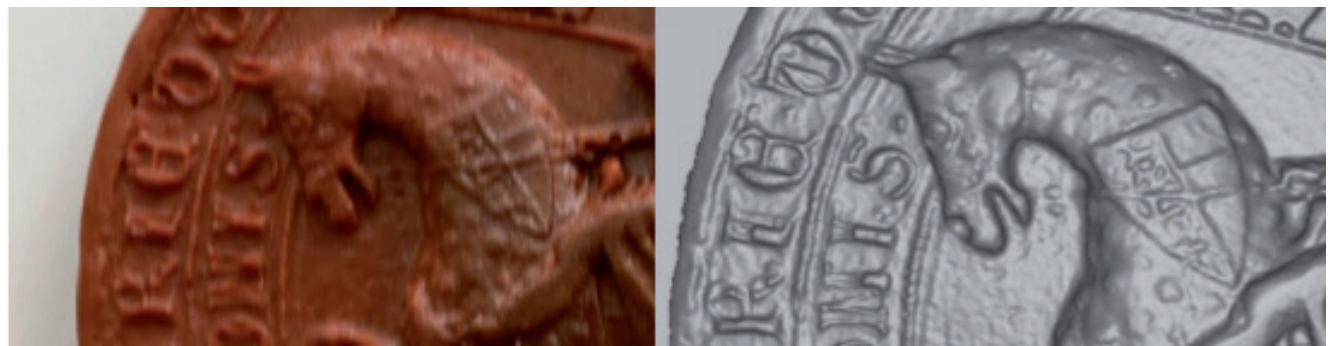

Obr. 2. Detailní srovnání fotografie a digitalizace pečeti Přemysla Otakara II

a zobrazení RTIViewer společnosti Cultural Heritage Imaging.

Pro optimální zachycení pečetí se jeví počet jednotlivých snímků $\mathrm{v}$ rozmezí od 20 do 70. Velikost výsledného digitalizátu je přibližně násobek velikosti dat pořízených fotografií pro RTIBuilder, což je stále zlomek datového objemu výstupů ze 3D skenerů. Zobrazovací software RTIViewer umožňuje variabilně nastavovat úhel osvětlení, což umožňuje snadnější čtení opisu a rozpoznání obrazu na pečetích.

\section{Další projekty a pracoviště využívající RTI metodu}

Mimo digitální laboratoře Centra digitálních historických věd Katedry Pomocných věd historických a archivnictví Filozofické fakulty Univerzity Hradec Králové lze po celém světě nalézt mnohé další zajímavé projekty a pracoviště, jež se zabývají uchování kulturního dědictví.

\section{Cultural Heritage Imaging}

Společnost Cultural Heritage Imaging se chopila velkého průkopnictví ve směru digitalizace kulturního dědictví po celém světě. Vytvořila rozsáhlé know-how, jež zpř́stupnila na svých webových stránkách, stojí za vznikem několika softwarů (open source i placených) a vytvořila technické sady pro začínající pracovníky v tomto odvětví.

Jako př́ílad práce této organizace je možné uvést digitalizaci nápisů a petroglyfů v El Morro ve spolupráci s americkou službou Národního parku a Centrem výzkumu ochrany University of Colorado v Denveru.
Nálezy v El Morro v Novém Mexiku se datují už od 1. století, kdy je zde zhotovili starověcí indiáni Zuni. Na konci 16. a počátku 17. století do této oblasti dorazili i španělští osadníci, kteří pořádali výpravy za stř́brem a zlatem. Během tohoto období začali Španělé dělat nápisy na skále, kterou nazývali El Morro. Pro návštěvníky je zajímavý tzv. Foxin nápis, kde se mohou vžít do příběhu dívky, která tudy prošla se svou rodinou cestou na západ. Erodující pískovec však lidem ztěžoval pozorování tohoto nápisu. V určité denní době, pod konkrétním úhlem a ve vyhovujících světelných podmínkách je text nápisu Sarah Fox čitelný, avšak po většinu dne kvůli slunečnímu úhlu je zcela nečitelný. Prostřednictvím RTI metody dokázal tým CHI odhalit všechny detaily tohoto nápisu.

Díky zachycení nápisů se všemi detaily mohli vědci zkoumat daleko podrobněji než skrze běžné fotografie. RTI metoda napomáhá vědcưm $\mathrm{s}$ různými záhadami a nezodpovězenými otázkami, které nápisy v El Morro stále skrývají. ${ }^{14}$

\section{The National Gallery, London}

Experty z The National Gallery v Londýně byl zkoumán povrch obrazů od Franse Halse, Julesa-Louise Duprého a Georgese Seurata právě pomocí PTM a RTI metody. Dvacet čtyři lamp bylo připevněno na kopulovitou konstrukci ve třech úrovních po osmi lampách. Kamera byla připevněna $\mathrm{v}$ horní části kopule a mírila kolmo dolů na obraz, jež byl na podlaze. Lampy byly ručně zapínány a vypínány pro každý snímek v sekvenci, podle preferovaného zachycení. Díky funkcím prohlížecího 
softwaru bylo možné vidět více struktur, než tomu bylo fyzicky za běžných světelných podmínek, což umožnilo expertízu vlastností povrchu obrazu, např. efekty stárnutí, defekty malby a deformace nosiče. ${ }^{15}$

\section{Cologne Center for eHumanities}

Vědci z Kolínské univerzity využívají RTI v projektu Magica Levantina, který se zaměřuje na edici převážně nepublikovaných řeckých textů $\mathrm{z}$ měst $\mathrm{v}$ Levantě $\mathrm{v}$ pozdně římské imperiální a rané byzantské době. Většina textů je dochována na olověných, zlatých nebo stř́ibrných plátech. Jednou z hlavních funkcí webových stránek projektu Magica Levantina bude zpř́stupnění textů veřejnosti v zobrazovací podobě RTI dokumentace, kterou sami autoři použili ke čtení textů. Web by měl také obsahovat výběr podpưrného fotografického materiálu zobrazujícího obrázky svitků před jejich otevřením. ${ }^{16}$

\section{Závěr}

Moderní fotografická metoda Reflectance Transformation Imaging odpovídá nejen na současné trendy $\mathrm{v}$ digitalizaci, ale zároveň umožňuje provádět digitalizační činnosti i takovým institucím, jenž nedisponují moderním digitalizačním pracovištěm. Částka na pořízení profesionálního vybavení pro 3D digitalizaci mnohdy sahá do výše několika milionů korun a ani časová náročnost zpracování dat zde není malá. Pro využití metody RTI není třeba mít rozsáhlé znalosti 3D modelování či velké technické nadání. Sestavení reprodukčního stojanu není technicky ani časově náročné a pro manipulaci s digitálními fotoaparáty bylo napsáno nepřeberné množství návodných publikací. Tvorba a zobrazení skrze RTI software je zprvu složitější, ale uživatele navede několik návodů sepsaných vědci z projektu $\mathrm{CHI}$ na jejich webových stránkách.

$Z$ několika konkrétních př́kladů lze konstatovat, že metoda RTI je odborníky oblíbená pro schopnost zachytit hmotné artefakty tvořící součást kulturního dědictví. Metoda je využitelná nejen v laboratořích či obecně interiérech, ale zároveň i v exteriérech. Další nespornou výhodou je fakt, že na velikosti digitalizovaného objektu zde nezáleží. Záleží samozřejmě na kvalitě digitálního fotoaparátu a použitého objektivu, ale digitalizovat lze od mincí přes pečeti po petroglyfy. S tím souvisí i schopnost RTI metody snímat různé textury a materiály objektů - od kovových povrchů mincí ke složité textuře malby na plátně.

\section{Zdroje}

BENTKOWSKA-KAFEL, Anna a Lindsay MACDONALD. Digital techniques for documenting and preserving cultural heritage: Collection Development, Cultural Heritage, And Digital Humanities [online]. Croydon: ARC Humanities Press, Kalamazoo and Bradford, 2017 [cit. 2021-9-26]. ISBN 9781942401346. Dostupné z: https://library.oapen. org/viewer/web/viewer.html?file=/ bitstream/handle/20.500.12657/42785/ $9781942401353 p d f$ ? sequence $=1 \&$ isAllowed $=\mathrm{y}$.

BREJCHA, Marcel, Vladimír BRŮNA, Zdeněk MAREK a Bára VĚTROVSKÁ. Metodiky digitalizace, 3D dokumentace a $3 D$ vizualizace jednotlivých typů památek [online]. Ústí nad Labem, 2015 [cit. 26.10.2021]. Dostupné z: https://www. npu.cz/publikace/metodika-digitalizace-3d-dokumentace-a-3d-vizualizacejednotlivych-typu-pamatek.pdf

Cultural Heritage Imaging [online]. San Francisco: Cultural Heritage Imaging, (C) 2002-2021 [cit. 2021-9-26]. Dostupné z: http://culturalheritageimaging.org/ About_Us/.

Documenting and Interpreting Petroglyphs and Inscriptions at El Morro National Monument [online]. San Francisco: Cultural Heritage Imaging, (c) 2002-2021 [cit. 2021-9-26]. Dostupné z: http://culturalheritageimaging.org/What_We_ Do/Projects/elmorro/index.html.

Documenting and Interpreting Petroglyphs and Inscriptions at El Morro National Monument [online]. San Francisco: Cultural Heritage Imaging, (c) 2002-2021
15 PADFIELD, Joseph, David SAUNDERS a Tom MALZBENDER. Polynomial texture mapping: a new tool for examining the surface of paintings. Academia [online]. 2005 [cit. 2021-9-26]. Dostupné z: https://www.academia. edu/19692440/Polynomial texture_mapping_a_new_tool_ for_examining_the_surface_of paintings.

16 Magica Levantina [online]. Kolín nad Rýnem: Cologne Center for eHumanities, (c) 2021 [cit. 2021-9-26].

Dostupné z: https://papyri. uni-koeln.de/magica-levantinal index.html. 
[cit. 2021-9-26]. Dostupné z: http://culturalheritageimaging.org/What_We_ Do/Projects/elmorro/index.html.

CHARR, Manuel. São Paulo Museum of Modern Art Opens on Minecraft. Museum Next [online]. Whitley Bay: Museum Next, 2021, 22. 6. 2021 [cit. 2021-9-16]. Dostupné z: https://www.museumnext. com/article/sao-paulo-museum-of-modern-art-opens-on-minecraft/.

Ima Solutions: 3D scanning $\mathcal{E}$ digital media [online]. Francie, 2021 [cit. 202110-29]. Dostupné z: https://ima-solutions.fr/technologies-and-know-how/ short-range-3d-scanning/.

JURDA, Mikuláš a Petra URBANOVÁ. Three-dimensional documentation of Dolní Věstonice skeletal remains: can photogrammetry substitute laser scanning? Anthropologie, Vol. 54, No. 2 (2016), pp. 109-116.

Magica Levantina [online]. Kolín nad Rýnem: Cologne Center for eHumanities, (c) 2021 [cit. 2021-9-26]. Dostupné z: https://papyri.uni-koeln.de/magica-levantina/index.html.

PADFIELD, Joseph, David SAUNDERS a Tom MALZBENDER. Polynomial texture mapping: a new tool for examining the surface of paintings. Academia [online]. 2005 [cit. 2021-9-26]. Dostupné z: https://www.academia.edu/19692440/ Polynomial_texture_mapping_a_new_ tool_for_examining_the_surface_of_ paintings.

Survey on the impact of the COVID-19 situation on museums in Europe: Final report [online]. Berlín: Network of European Museum Organisations, 2020 [cit. 2021-9-19]. Dostupné z: https:// www.ne-mo.org/fileadmin/Dateien/ public/NEMO_documents/NEMO_ COVID19_Report_12.05.2020.pdf.

The Network of European Museum Organisations. The Network of European Museum Organisations [online]. Berlin: NEMO, (c) 2021 [cit. 2021-9-27]. Dostupné z: ne-mo.org.

ZUZA, Mikolas. Fotogrammetrie - 3D skenování s použitím fotoaparátu či mobilu. Https://josefprusa.cz [online]. 2018 [cit. 2021-10-28]. Dostupné z: https://josefprusa.cz/fotogrammetrie-3d-skenovani-s-pouzitim-fotoaparatu-ci-mobilu/ 